\title{
Political Islam, Iran, and the Enlightenment: Philosophies of Hope and Despair
}

\author{
Ali Mirsepassi \\ New York: Cambridge University Press, 2011.pbk. 241 pages
}

Political Islam, Iran, and the Enlightenment is Mirsepassi's latest treatise that focuses on the Iranian intellectual and political climate. Mirsepassi is concerned to show the German and French intellectual influences of Islamist intellectuals as they search for an appropriate response to modernity. With Iran taken as a case study, Mirsepassi's discussion is intended to undermine those analyses of Muslim political aspirations which deem these aspirations to be inherently anti-Western. Comprising an introduction and seven chapters, Mirsepassi's work speaks to those researchers in a range of sociopolitical disciplines concerned with coming to grips with intellectual developments in the Muslim world. The book might also interest those interested in understanding the impact of continental philosophy on the Muslim world. Although the emphasis is on Iran, an attempt is made in the final chapter, especially, to broaden the discussion by dealing with the Indian experience of modernity.

According to Mirsepassi, the Muslim understanding of modernity and secularism was influenced by the specific visions of modern society held by Kemal Ataturk and the "Shah of Iran" (presumably the ambitious Reza Shah). These two figures were in turn influenced by the antireligious fervor of French secularism. The attempt of Muslim intellectuals, therefore, to establish a correct vision of society was informed by the radical CounterEnlightenment figures of German and French philosophy. Furthermore, Muslim intellectuals overlooked Western visions of modern society which were not antireligious. Political Islam, Iran, and the Enlightenment, therefore, constructs a narrative that leads to examining the experience of British-style secularism in India. Mirsepassi's fear is that a lack of appreciation of the European heritage of Islamists - who Mirsepassi sees as intellectually and politically totalitarian and as representing all Muslims - will lead to the sidelining of two groups from within the Muslim world. These two groups are the quietist ulama and the reformist intellectuals, the latter of which offer Mirsepassi the hope of an Islamic response to modernity that is consistent with democratic principles.

In chapter 1, Mirsepassi criticizes the highly theoretical debates among Iranian intellectuals, said to be started by Ahmad Fardid (1890-1994), 
which have no bearing on public concerns for democratization. The trend for these debates to be dominated by heavyweight intellectuals (or "master thinkers") is elitist and unaccepting of criticism and, therefore, detrimental to democratic social change. In chapter 2 , the insecurity caused by modernity is examined through an extended exploration of Tayeb Salih's novel, Season of Migration to the North. The insecurity, says Mirsepassi, gives rise to a nostalgic yearning for "roots" and a "spiritual home." Mirsepassi concludes that narratives of authenticity operating within a society are divisive.

Chapter 3 seeks to present an alternative to the divisive narratives of authenticity. For those interested in taking Iran through the troubles of modernity, one of the most important steps, argues Mirsepassi, is for Iranian intellectuals to undergo greater self-criticism of their heritage and tradition. The aim is to rise above despair - and polarities such as inside/outside and East/West - and instead to bring about progress and the recognition that the advancement of a society can be incremental. Oddly, the chapter is poorly referenced and even direct quotes are unreferenced. Thus, Mirsepassi's reading of recent and current intellectual history has to be taken on trust.

Chapter 4 sees the discussion of a theme highlighted in the introduction - specifically, the role of Heideggerian philosophy in contemporary Iranian political discourse. Heidegger's radical reaction to the European Enlightenment resulted in a call for absolute authority in tradition - in other words, an institutionalization of authenticity. This call was received well by Iranian intellectuals who had seen at first hand aggressive modernization programs. However, adherence to a Heideggerain philosophy has antidemocratic implications because democracy is pragmatic and not ideological or utopian.

Mirsepassi's preference for pragmatism leads him to examine the thought of John Dewey in chapter 5, specifically in relation to democracy and religion in modern societies. In chapter 6 , with heavy dependence on Gertrude Himmelfarb, Mirsepassi maintains that Britain, France, and the United States have each experienced a different Enlightenment. This means that there is no one path to modernity to be either followed or feared, but rather a nation can develop a form of modernity for itself that it considers suitable. Furthermore, when a nation does endeavor to develop its own expression of modernity, it may note that the British Enlightenment was more reforming and less alienating that the French Enlightenment.

Chapter 6 continues by Mirsepassi discussing the Indian independence and post-independence movements and the American civil rights move- 
ment, all as examples of radical yet nonviolent movements for change. The suggestion is that these movements have agitated for change in a positive way, as was the case with the British Enlightenment. The exploration of these movements also presents a comparison between the thought of Hegel (via Jawaharlal Nehru) and Dewey (via Mahatma Gandhi and Martin Luther King).

In the six chapters of Political Islam, Iran, and the Enlightenment, we can see that some chapters focus on narratives of hope - that is, pragmatic visions of social change, which offer hope that Muslim societies can experience democratic forms of modernity. Other chapters focus on narratives of despair - primarily ontological critiques of modernity, which yearn for a lost social order. It is not always easy to discern the connection between the chapters and, thus, the flow of the argument in the book. It is also difficult to discern how the Iranian fascination with Heideggerian philosophy is important for other Muslim nations. Indeed, the odd mention of Muhammad Abduh or Mohammed Arkoun and others does little to make explicit the meaning of Mirsepassi's arguments for the Muslim world outside of Iran. Yet, the voice of progression and the call for nuance in reactions to modernity is heard, and this is surely a worthwhile thing.

Amir Dastmalchian

Research Fellow, Department of Research and Publications

The Islamic College, London, UK The Islamic College, 133 High Road, Willesden, London NW10 2SW a.dastmalchian@islamic-college.ac.uk 